\title{
Students' Ability to Analyze the Moderation of Islamic Teachings on Islamic Cultural History Learning in Indonesia
}

\author{
Asep Nursobah*, Andewi Suhartini, Hasan Basri, Uus Ruswandi \\ Departement of Islamic Education \\ UIN Sunan Gunung Djati \\ Bandung, Indonesia \\ *kangasnur@uinsgd.ac.id
}

\begin{abstract}
Islamic Cultural History Learning (SKI) has an important role in building students' religious awareness. The acquisition of the lesson (ibrah) by students by referring to the original Islamic values, from the facts, concepts, principles, and procedures, within religiosity of the people in the past, allows the discovery of evidence of the superiority of moderate values that are the foundation of Islamic progress in history. This study aims to reveal the ability of high school (SMA) students to analyze the evidence of Islamic moderation in the SKI that they are studied in accordance with the 2013 curriculum on Islamic Religious Education and Budi Pekerti subjects, which includes the propaganda period of the Prophet Muhammad Saw in Makkah which is more focused on strengthening believe (aqidah) and carrying out clandestinely to be able to uphold the truth peacefully in the Quraysh community, the development of science on the Islamic civilization during its heyday as proof of Islamic moderation in the development of science supporting the implementation of worship, the cause of the decline of Islamic civilization caused by disobedience to Islamic teachings moderate (taking for granted foreign culture), the stagnation of science among Muslims in modern times as a result of an orientation towards prestige. This study uses a survey method, with the test as a data collection tool conducted at SMAN in Semarang, Bogor, and Makassar in the second semester of the 2019/2020 school year. The results showed that by thinking at a high level of analysis, students could find the values of Islamic moderation as a lesson from SKI learning. The implication of the findings of this study is to optimize the findings of Islamic moderation in learning SKI, among them, which can be done by learning to analyze various facts, concepts, and principles in SKI.
\end{abstract}

Keywords-higher order thinking skills, islamic moderate values, ibrah, islamic cultural history

\section{INTRODUCTION}

Islam is a religion which contains teachings that guide humans to live in a civilized life, even with other humans, who are led to jointly build world civilization. Historically, Rasulullah Muhammad saw and other messengers of Allah have made history with various facts and events that describe the process of transmitting and transforming the values of Islamic teachings to his followers to become the building foundation on world civilization. Islamic education is currently entrusted being the subject in an effort to transform the values of Islamic teachings and stimulate students to analyze, interpret and take lessons (ibrah) from the history of Islamic civilization. The students' analytical ability about the moderate history of Islamic civilization can strengthen their faith, strengthen their morals, and improve the quality and quantity of their worship, both individually and socially.

Several studies have been conducted on learning the history of Islamic culture, for example: e-learning-based Islamic Cultural History can improve student learning outcomes [1]. Learning Islamic Cultural History through the application of a power point-based scrumble learning model can improve student learning outcomes [2]. Learning the history of Islamic culture through a value analysis strategy can identify the differences in students' character [3]. Learning Islamic Cultural History cause a boredom if the learning is not fun, the students are tired, the methods are boring, the reference books are few, the tasks are not varied and the teacher's lack of attention [4]. Likewise, the research on the analytical ability of students has been conducted by many researchers, for example: PAI learning through the application of cooperative learning methods can improve students' critical thinking skills [5]. Critical thinking skills are characterized by academic abilities, mastery of concepts, and analytical skills [6]. Furthermore, the research on moderate Islamic values has been conducted a lot, for example: the values of tolerance and the wasathan ummatan reinforce the survival of a united and peaceful life [7]. The concept of aswaja, that are justice, balance, and tolerance as moderate Islamic values can resolve radicalism in Indonesia [8]. The importance of moderate values in educational institutions of Indonesia to resolve radicalism that leads to terrorism [9]. In addition, the basic map of moderate Islamic thought and puritan Islam in the Qur'an [10]. 
This study is focused on describing the analytical abilities of students about the moderate values of Islamic teachings contained in the Islamic Cultural History.

\section{Methods}

This study uses a qualitative approach to find a moderation content in the curriculum document, namely the content of competencies and materials in Permendikbud no. 87 of 2018. Furthermore, researchers expanded quantitative data mining by testing students' mastery of Islamic moderation material from PAI subject of the SKI aspects that are being studied. In addition, moderate Islamic mastery is revealed through interviews with students. Based on these two approaches, qualitative and quantitative, this study uses mixed methods. This research begins with extracting qualitative data followed by quantitative data and then interpreting it.

The types of data in this study are qualitative and quantitative. The qualitative data are related to the statements in the curriculum content and Islamic Religious Education teachers which show the moderation of Islam that students learn. The quantitative data are the scores obtained by students from the analytical ability test of PAI material in term of history at Senior High Schools in West Java, Central Java and South Sulawesi. This research was conducted in SMAN of West Java, Central Java and South Sulawesi, consists of: 1) SMAN 2 Bogor City; 2) SMAN 1 Bogor Regency, 3) SMAN 3 Semarang; 4) SMAN 10 Semarang; 5) SMAN 2 Makassar; and 6) SMAN 7 Makassar. The data source of this research was selected purposively by determining schools which had shown the success in implementing moderate Islamic Religious Education. The subjects consist of: (1) Principal; (2) Deputy Chief; (3) PAI teachers, and (4) SMAN students in West Java, Central Java and South Sulawesi.

To obtain the data needed in this study, the collection techniques used were tests, observation, interviews and documentation. The test is used as a data collection technique regarding higher-order thinking skills in determining the moderation of Islamic teachings on the PAI material aspects of the IHS that students learn. The test instrument is arranged based on the outline that refers to the basic competencies of Islamic Education in class X and XI of SMAN. Observations were made through observation, including the activity of observing students' activities in interpreting moderate Islam in historical aspects. Interviews were conducted to obtain information from educators and students about various activities related to learning Islamic religious education aspects of the IEC which encourage moderate religion. In this case the researcher uses the unstructured interview type, which is a combination of free interviews and guided interviews. Technically, the researcher uses guidelines which are the outline about the things that will be asked. Interviews are also used to examine in depth the experiences of students in answering the test instrument regarding Islamic moderation in the material of Islamic Education in the aspects of the IEC. The author interviewed school's principals, deputy chief, Islamic education teachers, and high school students in West Java,
Central Java and South Sulawesi. Documentation includes the collection of documents of the learning implementation plan, especially on the components of Islamic Education learning materials and the IAH aspect of the PAI book. By examining the contents of the learning materials in the lesson plans and the PAI book on the aspects of the SKI, the researcher can determine the level of coverage of the Islamic moderation material in the SKI aspects of the RPP and the PAI book.

At the data processing stage, the data that has been collected is identified, criticized and clarified in accordance with the research systematics and analyzed with content analysis. Finally, the results of data analysis are included in a research report. The data analysis process in this study went through three phases of activity, namely data reduction, data presentation and conclusion or verification. Data analysis was carried out by systematically compiling the data obtained from the results of tests, interviews, observations and documentation by organizing the data into categories in the term of strategies, patterns and meanings obtained through higher-order thinking to determine the moderate Islamic aspects of the IEC carried out by the students then describing them into units which include the time of implementation, the sequence of implementation, and the place of implementation. After that, doing synthesize, arranging them into patterns, choosing which one is important and what will be studied, and making conclusions in order to be easily understood by oneself and others.

\section{RESULTS AND DISCUSSION}

In this section, research data is presented in order to answer research questions about the analytical ability of students at SMAN 2 Bogor City, SMAN 1 Kab. Bogor, SMAN 3 Semarang, SMAN 10 Seamarang, SMAN 7 Makasar and SMAN 2 Makasar on the aspects of SKI, both qualitatively and quantitatively, as follows:

According to the table above, the students' analytical ability towards the SKI material obtained the highest score in DM (Da'wah of the Prophet in Mecca), which is 0.858. Meanwhile, the one that is considered the lowest is in KMD (Stagnation of Science), which is 0.375 . This is consistent with the difference average score of the four aspects, that turns out the aspects of science's stagnation is 0.375 the lowest among the cause aspects of decline of Islamic civilization, which is 0.688 , the development of science, which is 0.747 , and the mission of the apostle in Mecca, which is 0.858 .

Based on the aspect of the cause of the Prophet Muhammad's da'wah in Mecca for 3 years, focusing more on strengthening aqidah and was done in secret, the following scores were obtained: SMAN 2 Bogor City with score of 0.81 , SMAN $1 \mathrm{Kab}$. Bogor with score of 0.72, SMAN 3 Semarang with score of 1 , SMAN 10 Semarang with score of 0.97 , SMAN 7 Makassar with score of 0.8 and SMAN 2 Makasar with score of 0.85 . The average score of the causes of the Prophet Muhammad's da'wah in Mecca for 3 year, focusing more on strengthening aqidah and was done in secret, reaches 
0.858 score which is very high because it is in the interval 0.80 - 1. Based on the six SMAN, it shows that the highest score is 1 and the lowest score is 0.72 .

The scores of students' analytical ability regarding moderation of historical aspects was obtained by giving the students a question "da'wah of the Prophet Muahammad Saw in Mecca for 3 years, focusing more on strengthening aqidah, was done in a secret because the Prophet ...". Based on this question, the answers of several students were found, including: students who answered A (paying attention to the situation of society in upholding the truth peacefully) were 408, students who answered B (hiding the truth in the Quraish musyrikin society) were 31, students who answered C (fear of facing the Quraish musyrikin people) were 7, and students who answered D (considering the feelings of the Quraish people) were 21. The correct answer is in the option A (paying attention to the situation of society in upholding the truth peacefully) which has 408 student's answers and the highest wrong answer is in the option B (hiding the truth in the Quraish musyrikin society) which has 31 student's answers.

According to the data above, there are 408 students who answered correctly (paying attention to the situation of society in upholding the truth peacefully). This shows that the students have the ability to think at a higher level in the term of analyzing religious moderation in the historical aspects of Islamic culture. In other words, students are not only able to interpret da'wah as the delivery of the message of Islamic teachings but also be able to interpret da'wah that is in accordance with the existing society context.

Furthermore, the score of students' analytical ability on the SKI aspect of science developed rapidly in the era of Islamic civilization during its heyday, presented as follow: SMAN 2 Bogor City with score of 0.75, SMAN 1 Kab. Bogor with score of 0.7, SMAN 3 Semarang with score of 0.93, SMAN 10 Semarang with score of 0.96 , SMAN 7 Makassar with score of 0.63 and SMAN 2 Makassar with score of 0.51. The average score of the SKI aspect is 0.747 , included into high category because it is in the interval $0.60-0.79$. Based on the six SMAN, the highest score is in SMAN 10 Semarang with 0.93 and the lowest score is in SMAN 2 Makassar with 0.51 .

To measure students' analytical ability about the moderation of Islamic history, the following question is being asked: "Science developed rapidly in the era of Islamic civilization at its heyday. This is caused by moderate Islamic teachings in the development of science for ... ". Based on this question, several student's answers were found including: students who answered A (to support the implementation of worship) were 361, students who answered B (expanded state's power) were 37 , students who answered $\mathrm{C}$ (to take control the economics field) were 42 , and students who answered D (to take control politics) were 18. The correct answer is in option A (to support the implementation of worship) that has 361 student's answers, while the highest wrong answer is in option C (to take control economics field) that has 42 student's answers.
Based on the data above, there is a total of 361 students answered correctly (supporting the implementation of worship). This shows that students have the ability to think at a high level in the term of analyzing religious moderation in aspects of the history of Islamic culture by analyzing the factors that caused the rapid development of science in the era of Islamic civilization on its heyday due to moderate Islamic teachings in the development of science to support the implementation of worship.

The score of students' analytical ability regarding the decline of Islamic civilization as a result of disobedience to moderate Islamic teachings, presented as follow: SMAN 2 Bogor City with score of 0.63, SMAN 1 Kab. Bogor with score of 0.63 , SMAN 3 Semarang with score of 0.79, SMAN 10 Semarang with score of 0.91 , SMAN 7 Makassar with score of 0.53 and SMAN 2 Makassar with score of 0.66. The average score for the decline of Islamic civilization as a result of disobedience to moderate Islamic teachings is 0.6883 , included into high category because it is in the interval $0.60-0.79$. According to the six SMAN, the highest score is in SMAN 10 Semarang with 0.91 and the lowest score is SMAN 7 Makassar with 0.53 .

To measure the analytical ability of students about the moderation of Islamic history, the following question is being asked: "The factor of the decline of Islamic civilization as a result of disobedience to moderate Islamic teachings is ...". Based on this question, it was found that: students who answered A (open to society development guidance) were 60, students who answered B (responsive to the challenges of the outside world) were 28 , students who answered C (simply accepting outside cultures) were 336, and students who answered D (critical towards the outside cultures that are considered new) were 36 . The correct answer is in option C (simply accepting outside cultures) that has 336 student's answer, while the highest wrong answer is in option A (open to society development guidance) that has 60 student's answer.

Based on the data above, there is a total of 336 students answered correctly (simply accepting outside cultures). This shows that students have the ability to think at a high level in the term of analyzing religious moderation in the historical aspects of Islamic culture by analyzing the factors that cause the decline of Islamic civilization as a result of disobedience to moderate Islamic teachings by simply accepting outside cultures.

Moreover, the scores of students' analytical ability of the SKI aspect regarding the causes of science stagnation among Muslims in modern times, presented as follow: SMAN 2 Bogor City with score of 0.53 , SMAN $1 \mathrm{Kab}$. Bogor with score of 0.35 , SMAN 3 Semarang with score of 0.82, SMAN 10 Semarang with score of 0.18, SMAN 7 Makassar with score of 0.17 and SMAN 2 Makassar with score of 0.19 . The average score of the causes of science stagnation among Muslims in modern times is 0.375 , included into the low category because it is in the interval $0.20-0.39$. According to six SMAN, the highest score was obtained by SMAN 3 Semarang with 0.81 
and the lowest score was obtained by SMAN 2 Makassar with 0.21 .

The analytical ability of students in the aspect of SKI is measured by asking the following question: "science has stagnated among Muslims in modern times, it is caused by ...". Based on this question, the students' answers were: students who answered A (prioritizing knowledge to support the implementation of worship) were 205, students who answered B (orienting knowledge for prestige) were 156, students who answered C (showing honesty) were 58, and students who answered D (did a lot of ijtihad) were 38 . The correct answer is in option B (orienting knowledge for prestige) that has 156 student's answer, while the highest wrong answer is in option A (prioritizing knowledge to support the implementation of worship) that has 205 student's answer.

According to the data above, there is a total of 156 students answered correctly (orienting knowledge for prestige). This shows that students have the ability to think at a high level in the term of analyzing religious moderation in aspects of the history of Islamic culture by analyzing the factors that cause science stagnation among Muslims in modern times which is because Muslims orient knowledge towards prestige.

The result of the average score of the analysis on the aspect of SKI about four things which are: the cause of the da'wah of the Prophet Muhammad in Mecca for 3 years focusing more on strengthening aqidah and was done in a secret, the cause of science developed rapidly in the era of Islamic civilization during its heyday, the decline of Islamic civilization as a result of disobedience to moderate Islamic teachings, and science has stagnated among Muslims in modern times, is $0.85+0.74+$ $0.68+0.37: 4=0.667$. The score is in the high category because it is in the interval $0.60-0.79$.

The importance of higher-order thinking skills in learning the history of Islamic culture is caused by the nature of history itself. Historians write history based on the facts obtained by exerting all their abilities to understand the spirit of the times' (zeit geist) event in the past written by historians. In addition, historical books which are used as teaching materials for students in schools will be influenced by the spirit of the author's era and the events that are brought up, such as historical textbooks in the 1997 to 2004 curriculum which are heavily influenced by the spirit of the interests of the New Order government [11].

The moderation of Islam that students get from learning SKI is the result of the high-level thinking process of students in finding the values that exist in the facts of events written by historians. Students can find ibrah about the moderation of Islam in the history of the prophet's da'wah in Mecca which is more caused by thinking process that is not only memorize but also obtained by linking the truth of Islamic teachings taught by the Prophet Muhammad with efforts to maintain peace, which is paying attention to the situation of society in upholding the truth. The fact of secretly da'wah is not interpreted as hiding the truth in the Quraish musyrikin society, fear of facing the Quraish musyrikin people or considering the feelings of the Quraish people. Memorizing the facts of an event is not sufficient enough for the students, they need to do analysis to show the connection between a fact with other facts from an event [3].

The value of Islamic moderation, displayed in the history of the Prophet Muhammad's da'wah in Mecca, is an important lesson for the students by connecting the fact about the importance of upholding the truth as an order of Allah SWT with the importance of how to uphold the truth peacefully. That is the reason da'wah was done secretly. The existence of a paternalistic Quraish society under the leadership of tribal leaders with a number of traditions that were deeply rooted in society at that time was slowly being transformed by Islamic principles that prioritize monotheism. Islam taught by Rasulullah SAW encourages people to adherence towards beliefs about unity, brotherhood and cooperation as a manifestation of faith in the Oneness of Allah in all creation, its rules and will [12].

The value of Islamic moderation also shows in the history of the development of scientific knowledge (PIP) during the heyday of Islam which made society becomes peaceful and prosperous, because science was developed to support the implementation of worship. In this case, the students can find lessons (ibrah) by linking the implementation of worship with the development of science. The artifacts of the development of science at that time were in the form of the main knowledge of worship, such as the science of tafsir, hadith, and fiqh. In addition, the knowledge that support worship are developed, such as mosque architecture, arithmetic (mathematics) and astronomy to make it comfortable and ensure accuracy in worship. Moreover, medical science can be interpreted as a support for healthy worship. To find the moderation of Islam in the historical facts of scientific progress in the heyday of Islam, students are proven to have the ability to connect it with the interests of the implementation of worship, not only to connect it with the effort to empower economic assets for the benefit of individual or state. This is in line with the moderation of Islam in the economic aspect, which emphasizes the balance between individual ownership and social welfare in order to reach the society discipline [13]; The moderation of Islam is also shown by the teaching that requires worship based on adequate knowledge, and developing knowledge whose usefulness is felt by the ummah as worship [14].

Ibrah about the importance of Islamic moderation is also found in the history of the decline of Islamic civilization. This was obtained by students by relating the facts of the collapse of the government and the development of a power-oriented civilization as a form of disobedience to moderate Islamic principles. Students are proven to be able to distinguish between responsiveness and being open or critical of accepting civilizations outside Islam. From various historical facts, it is proven that the decline of Islam is more caused by the attitude of the Muslim's society which simply accepts foreign culture [15]. A critical attitude towards a new culture is important in Islamic moderation, so that the openness of Islamic teachings is known better among fiqih scholars, which is the principle of 
maintaining old traditions that are still believed to be good and accommodating new traditions that are believed to be better (al-muhafadhatu 'ala al-Qadiim al -shalih wa al-akhdzu bi aljadid al-ashlah) [16]. This critical attitude shows that Islam is moderate in facing new changes and progress (not rejecting and taking it for granted).

Even in modern history, the Islamic ummah has fallen behind even has stagnated in developing science. The lesson (ibrah) from the history of stagnation is also in line with the lessons learned from the decline of the Islamic civilization that is the Islamic ummah's disobedience to the principle of moderation of Islamic teachings in developing science. Islam encourages its ummah to achieve a balance between worldly interests (profane) and the hereafter by orienting profanes to the sacred. In addition, the attainment of science must be oriented towards the need for the implementation of worship.

The ability of students to find ibrah from the decline of the Islamic civilization in modern times as a result of disobedience to the moderate principle of Islamic teachings is relatively low. Overall, the average score of students' ability to find lessons (ibrah) from the history of scientific stagnation among Muslims in modern times is in the low category, which is 0.37 . This finding can be interpreted that students have not been fully able to analyze the necessity to develop knowledge related to the moderation of Islamic teachings regarding the obligation to study. However, students from SMAN in the downtown (SMAN 2 Bogor city SMAN 3 Semarang city) have a higher average score compared to SMA in the suburban (SMAN 1 Kab. Bogor, SMAN 10 Semarang, SMAN 2 and SMAN 7 Makassar) regarding to the ability to analyze historical facts of the Islamic ummah in modern times. With various modern information and communication technology facilities, students in the downtown more come up about the orientation of modern society in terms of science for the achievement of prestige [17].

The acquisition of values from historical facts (ibrah) of the Prophet Muhammad's hidden message in Mecca and the advancement of science in the heyday of Islam as evidence of the moderation of Islamic teachings that emphasizes peaceful ways in conveying the truth, and the development of science for the realization of tasks as the main human being, namely as a servant of Allah and as a leader (caliph) who embodies various good deeds for human life. Moreover, the important value of the history of the stagnant development of science in the decline and modern times is as evidence of Islam's disobedience to the principles of moderate Islamic teachings. The students obtained these values by analyzing various historical facts, as a form of higher order thinking, especially during the learning process of the history of Islamic culture in high school, which is not only memorizing facts in historical events.

\section{CONCLUSION}

Based on the discussion as described above, the research shows that by high-level thinking at the level of analysis, students can find Islamic moderate values as ibrah from learning SKI. The implication of the findings of this study is to optimize the findings of Islamic moderation in learning $\mathrm{ICH}$, among other things, by learning to analyze various facts, concepts and principles in SKI.

\section{REFERENCES}

[1] E. Sofi, "Pembelajaran Berbasis E-Learning Pada Mata Pelajaran Sejarah Kebudayaan Islam Kelas Viii Madrasah Tsanawiyah Negeri," Tanzhim, vol. 1, no. 01, pp. 49-64, 2017.

[2] D. Fitria and J. Andriesgo, "Penerapan model pembelajaran scramble berbasis powerpoint untuk meningkatkan hasil belajar siswa pada bidang studi sejarah kebudayaan Islam," J-PAI: Jurnal Pendidikan Agama Islam, vol. 5, no. 2, 2019.

[3] U.M.K. Abdullah and A. Azis, "Efektifitas Strategi Pembelajaran Analisis Nilai Terhadap Pengembangan Karakter Siswa Pada Mata Pelajaran Sejarah Kebudayaan Islam," Jurnal Penelitian Pendidikan Islam,[SL], vol. 7, no. 1, pp. 51-62, 2019.

[4] N. Fauziyah, "Faktor Penyebab Kejenuhan Belajar Sejarah Kebudayaan Islam (SKI) pada Siswa Kelas XI Jurusan Keagamaan di MAN Tempe Sleman,” Jurnal Pendidikan Agama Islam, vol. 10, pp. 99-108, 2013.

[5] N. Mumtahanah, "Meningkatkan Kemampuan Berpikir Kritis Siswa Melalui Metode Cooperative Learning dalam Pembelajaran PAI," Al Hikmah: Jurnal Studi Keislaman, vol. 3, no. 4, 2013.

[6] T.I. Permana, I. Hindun, N.L. Rofi'ah, and A.S.N. Azizah, "Critical thinking skills: The academic ability, mastering concepts, and analytical skill of undergraduate students," JPBI (Jurnal Pendidikan Biologi Indonesia), vol. 5, no. 1, pp. 1-8, 2019.

[7] A.A. Abdurrohman, "Eksistensi islam moderat dalam perspektif Islam," Rausyan Fikr: Jurnal Pemikiran dan Pencerahan, vol. 14, no. 1, 2018.

[8] E. Prasetiawati, "Menanamkan Islam Moderat untuk Menanggulangi Radikalisme di Indonesia," Fikri: Jurnal Kajian Agama, Sosial dan Budaya, vol. 2, no. 2, pp. 523-570, 2017

[9] S. Hadi, "Urgensi Nilai-Nilai Moderat Islam Dalam Lembaga Pendidikan Di Indonesia," KAHPI, vol. 1, no. 1, 2019.

[10] C. Wahyudi, "Tipologi Islam Moderat dan Puritan: Pemikiran Khaled M. Abou el-Fadl," Teosofi: Jurnal Tasawuf dan Pemikiran Islam, vol. 1, no. 1 , pp. 75-92, 2011

[11] M. Marlina, "Pengaruh Zeitgeist Terhadap Muatan Sejarah di Buku Teks Pelajaran Sejarah SMA Kurikulum 1975-2004," Indonesian Journal of History Education, vol. 4, no. 1, 2016.

[12] I. Choli, "Pembentukan Karakter Melalui Pendidikan Islam," Tahdzib Al-Akhlaq: Jurnal Pendidikan Islam, vol. 2, no. 2, pp. 35-52, 2019.

[13] N.E.K. Aprianto, "Kontruksi Sistem Jaminan Sosial dalam Perspektif Ekonomi Islam,” Economica: Jurnal Ekonomi Islam, vol. 8, no. 2, pp. 237-262, 2017.

[14] M. Usman, "Dialektika Islam dan Ilmu Pengetahuan Studi Wahdat al"Ulūm Menurut al-Ghazali," Fikroh: Jurnal Pemikiran dan Pendidikan Islam, vol. 13, no. 2, pp. 81-103, 2020.

[15] F. Hasyim, "Ilmu Pengetahuan dan Perkembangannya: Tantangan Kemajuan dan Kemunduran Dunia Muslim," ULUL ALBAB Jurnal Studi Islam, vol. 13, no. 1, pp. 1-17, 2012.

[16] E.F. Rusydiyah, "Konstruksi sosial pendidikan pesantren: analisis pemikiran Azyumardi Azra," Jurnal Pendidikan Agama Islam, vol. 5, no. 1 , pp. $21-43,2017$

[17] A. Idrus, "Pemanfaatan teknologi informasi dan komunikasi dalam layanan administrasi akademik terhadap peningkatan kinerja di sma negeri kota jambi," Jurnal Tekno-pedagogi, vol. 4, no. 2, 2014 